Artigo original

Hegemonia - Revista Eletrônica do Programa de Mestrado em Direitos Humanos, Cidadania e Violência/Ciência Política do Centro Universitário Unieuro

ISSN: 1809-1261

UNIEURO, Brasília, número 26, Janeiro a Junho de 2019, pp. 95-113.

Recebido em: 13/08/2018

Avaliado em: 5/09/2018

Aprovado em: 17/11/2018

\title{
MITIGAÇÃO DO PACTA SUNT SERVANDA EM FACE DA BOA-FÉ OBJETIVA
}

José Henrique Ferreira Gonçalves ${ }^{1}$ e José Felicio Bergamim²

RESUMO: Com a promulgação da Constituição da República de 1988 (CR/88), o Estado brasileiro passou a adotar novos critérios em sua organização, migrando de uma visão singular para uma visão coletiva do direito. É justamente essa mudança de paradigmas, de influencias do Estado Liberal para o Social, que gerou profundas mudanças no direito contratual. Nesse ponto se afirma que a boa-fé-objetiva equilibra as relações contratuais e tem importância capital nas manifestações de vontade. Em sendo assim, a vontade que antes fazia lei entre as partes, independente de norma impositiva sobre como devia ser externada, deixou de ser o único elemento das relações contratuais.

Palavras-chave: Contratos. Contratos. Direito Civil Autonomia da vontade. Boa-fé objetiva.

ABSTRACT: The Brazilian contract law, has experienced an extensive revolution. In order to establish a legal system that meets the aspirations of the welfare state, the basis on which contract law was originally founded had to change. Prior to the National Constitution of 1988, Brazil adopted a freedom of contract point of view. This paradigm shift implied that good faith, as a behavioral model, balances contractual relations, in order to avoid abuse from any party. That being so, the will to engage in a contract, which was once purely free, independent, is no longer the only element of contractual relationships. The majority of Portuguese-speaking law professors call this phenomenon of limiting freedom of agreements in order to avoid abuses of contractual dirigisme.

Keywords: Contracts. Constitutional Law. Civil Law. Freedom of contract. Good faith.

1 INTRODUÇÃO

O presente artigo visa tratar da extensa revolução que o direito contratual brasileiro experimentou em razão da constituição vigente. Isso porque, com vistas a estabelecer um sistema

\footnotetext{
${ }^{1}$ Bacharel em Direito.

2 Doutor em Direito, e docente do Centro Universitário Estácio-Facitec.
} 
Artigo original

Hegemonia - Revista Eletrônica do Programa de Mestrado em Direitos Humanos, Cidadania e Violência/Ciência Política do Centro Universitário Unieuro

ISSN: 1809-1261

UNIEURO, Brasília, número 26, Janeiro a Junho de 2019, pp. 95-113.

jurídico que atenda aos anseios do Estado Social, as bases sobre as quais estavam inicialmente fundadas as noções principais desse ramo foram estremecidas, para fins de ofertar espaço a uma nova visão coletiva do direito.

Dentre os pilares que sofreram modificações, merece maior relevância aquele que compõe a manifestação da vontade e como esta deve ser dirigida para o estabelecimento das relações obrigacionais.

É nesse ponto que se afirma que a boa-fé, enquanto modelo comportamental, equilibra as relações contratuais, pois tem importância capital na formalização e leitura dos contratos, sobretudo, como já mencionado, em razão da nova ordem constitucional de 1988, do Código de Defesa do Consumidor e, por fim, com a chegada do Código Civil de 2002.

A vontade, que antes era puramente livre, independente de norma impositiva sobre como devia ser externada, deixou de ser o único elemento central das relações contratuais como era no passado, quando se impunha a cogente observância dos termos que haviam sido pactuados (pacta sunt servanda). Toma especial relevância no ordenamento jurídico vigente o contrato como função social, restando a vontade das partes vinculada a uma série de normas que visam ao bem comum, mesmo que signifique revisar o que fora pactuado entre particulares.

Por conseguinte, ao se estender a noção do que seriam as bases contratuais que deveriam ser atendidas na formação do negócio jurídico, acabou-se por criar um aparente choque entre os princípios da boa-fé e o da manifestação livre de vontades.

A resolução dessa possível crise entre princípios, conforme se verificará, deve ser alcançada pela observância do Direito como um produto de sua sociedade, o qual somente existe dentro de uma visão coletiva em detrimento daquela superada visão individualista do contrato.

Para tanto, a fim de se construir um raciocínio lógico que permita alcançar a magnitude do tema ora enfrentado, além de enfrentar os aspectos históricos que serviram como elementos para a construção do direito civil contratual vivenciado no Brasil durante a vigência do Código de 1916, pretende-se abordar o fenômeno da constitucionalização do direito civil, pelo qual, em apertada síntese, a lei deve ser interpretada com um verdadeiro filtro que é a Constituição Federal/88 (CF/88). 
Artigo original

Hegemonia - Revista Eletrônica do Programa de Mestrado em Direitos Humanos, Cidadania e Violência/Ciência Política do Centro Universitário Unieuro

ISSN: 1809-1261

UNIEURO, Brasília, número 26, Janeiro a Junho de 2019, pp. 95-113.

\section{SÍNTESE DA EVOLUÇÃO HISTÓRICA}

Não há dúvidas de que as normas relacionadas ao direito contratual, tal como hoje são albergadas pelo Direito pátrio e praticadas pela sociedade, são resultado de longa construção, que se deu através dos anos.

A partir do momento em que as pessoas passam a negociar seus bens e direitos, surge um conflito de interesse, pois é natural a presença de eventuais excessos e abusos, sobretudo porque, infelizmente, é da natureza humana privilegiar os interesses particulares/individuais. (MARQUES, 1999, p. 38)

Para delimitar anseios individuais em busca de um fim comum criou-se a figura do contrato, negócio jurídico que abarca conjunto de regras entabuladas entre partes distintas com o fim de se estabelecer previamente a devida conduta do acordo.

A análise jurídica aprofundada sobre os contratos, em documentos históricos, só teve seu início nos tempos do direito romano, tendo como base as práticas sociais da época sendo, então, o contrato um produto da realidade social desde sua origem. (MARQUES, 2002, P. 37)

Naquele tempo, o contrato tinha um caráter rigoroso e sacramental, de modo que o seu conteúdo deveria ser cumprido, ainda que não expressasse exatamente a vontade das partes. No mais, a solenidade era requisito essencial para que se criasse uma obrigação. (VENOSA, 2003, p. 364-365)

A visão romana triunfou na Europa Continental e sobre as suas colônias ao redor do globo terrestre por longos anos, tendo encontrado reforço no direito canônico, na idade média, com a contribuição da promessa ser capaz de gerar efeitos vinculantes, mesmo sem assinatura de um pacto o homem estaria vinculado à sua palavra empenhada (MARQUES, 2002, p. 44).

Nessa ótica, conhecida como a autonomia da vontade clássica, geradora do brocado pacta sunt servanda, que indica o imperativo de cumprir o pactuado, observa-se a rigidez da interpretação dos contratos. Restava ao Estado, ainda nesse contexto, o papel de garantidor do cumprimento do acordo. Tal teoria foi reforçada pelos iluministas e fortemente difundida nas codificações que seguiram a essa era, dentre as quais se pode destacar o Código Civil Napoleônico/1804 (MARQUES, 1999, p. 37-239). 
Artigo original

Hegemonia - Revista Eletrônica do Programa de Mestrado em Direitos Humanos, Cidadania e Violência/Ciência Política do Centro Universitário Unieuro

ISSN: 1809-1261

UNIEURO, Brasília, número 26, Janeiro a Junho de 2019, pp. 95-113.

Natural concluir, em uma primeira análise, que uma vez pactuado de forma livre e desembaraçada, nada deve intervir na vontade das partes, o que gera segurança aos contraentes e encoraja o homem a realizar mais avenças.

Veja que, as máximas de liberdade, igualdade e fraternidade e, por conseguinte, o pacta sunt servanda, deram ensejo à pujança da burguesia, ao criar uma nova forma de circulação de bens para toda a sociedade, diversa da herança, típica da nobreza da Europa Medieval.

Ao tratar dos ideais clássicos supramencionados incorporados ao direito brasileiro, insculpidos no Código Civil de 1916, Rogério Ferraz Donnini (2001, p.3-4) aponta que:

No direito clássico, a liberdade de contratar, a força obrigatória dos contratos e os efeitos destes vinculando apenas os contratantes (princípio da relatividade dos contratos) representam os principais fundamentos da teoria clássica dos contratos, em que se dão a oferta e a aceitação, o livre consentimento e a igualdade formal dos contratantes. É o chamado modelo liberal, seguido não só pelo nosso Código Civil, mas pelas principais leis civis substantivas do final do século passado e início deste.

O contrato, nesse modelo liberal, faz lei entre as partes, e a sua força é conhecida no bocardo pacta sunt servanda. Destarte, se os contraentes são livres para celebrar um pacto e o fazem, passam a assumir todas as obrigações convencionadas, segundo a vontade manifestada, devendo, pois, ser cumprido aquilo que foi acordado.

Voltando ao rumo da evolução do Direito Europeu no século XX, segundo Carlos Alberto Bittar Filho (1992, p. 21), uma serie de eventos determinaram uma guinada para um novo padrão de compreensão do direito contratual naquele continente. O que levou a uma releitura de antigas teorias que já previam a possibilidade de pactos serem revisados em juízo. Dentre deles destaca-se a Primeira Guerra Mundial, que alterou significativamente as relações obrigacionais entabuladas anteriormente e principalmente o contexto econômico em que estavam inseridas. Seguiu-se à primeira grande guerra severa instabilidade econômica, o que abalou a segurança das relações contratuais avençadas antes do abalo socioeconômico. 
Artigo original

Hegemonia - Revista Eletrônica do Programa de Mestrado em Direitos Humanos, Cidadania e Violência/Ciência Política do Centro Universitário Unieuro

ISSN: 1809-1261

UNIEURO, Brasília, número 26, Janeiro a Junho de 2019, pp. 95-113.

Em face dos imprevistos que permearam o século passado, conforme registra Álvaro Villaça Azevedo (2005, p. 33), os Estados passaram a lançar mão de normas cogentes para interferir nas relações contratuais justamente no intuito de garantir o equilíbrio dos contratos.

Como destaque, em França, a lei Faillot de 1918 instituiu normas capazes de relativizar os pactos, para permitir a revisão desses em juízo sempre que eventos imprevisíveis alterassem significativamente o contexto em que as obrigações foram originalmente celebradas. A esse fenômeno que possibilitava a flexibilização de pactos de trato sucessivo, face ao imprevisto, se deu o nome de cláusula rebus sic stantibus. Referido termo, também conhecido por teóricos do direito como teoria da imprevisão.

Convém observar que, conquanto não haja unanimidade entre os estudiosos, essa cláusula já havia sido esboçada pelos jurisconsultos romanos, sem que, naquele tempo, houvesse uso prático entre os patrícios. E, embora possa encontrar-se fragmentos de seus preceitos desde o Código de Hamurabi, e, de forma esparsa em legislações europeias antes da chegada do século $\mathrm{XX}$, somente nesse período tomou os contornos vistos na contemporaneidade (DONNINI, 2001, p. 3-22).

Para fins de aplicação daquela cláusula, e consequente revisão/resolução do contrato, três elementos deveriam estar presentes: (i) que o evento modificador do contexto tivesse ocorrido depois da celebração do contrato; (ii) que este evento não pudesse ser previsto por qualquer das partes; e (iii) que o imprevisto gerasse excessiva onerosidade a uma das partes, em razão da qual, portanto, justo seria o não cumprimento tal qual inicialmente entabulado.

Logo, a ampla aplicação da cláusula rebus sic stantibus, significou uma primeira mitigação do pacta sunt servanda, após a consolidação da teoria da autonomia da vontade, em prol de proteger as partes que atuavam pautadas pela boa-fé e presenciavam os termos contratuais se tornarem demasiadamente onerosos em face de eventos imprevisíveis ao tempo da avença.

Nesse aspecto, Claudia Lima Marques (1999, 37-239) veio a denominar essa migração da teoria clássica da autonomia da vontade para a intervenção estatal nos contratos em busca do justo, para além do pacto, de a nova ordem contratual. 
Artigo original

Hegemonia - Revista Eletrônica do Programa de Mestrado em Direitos Humanos, Cidadania e Violência/Ciência Política do Centro Universitário Unieuro

ISSN: 1809-1261

UNIEURO, Brasília, número 26, Janeiro a Junho de 2019, pp. 95-113.

\section{A CONSTITUCIONALIZAÇÃO DO DIREITO CIVIL}

A par do contexto histórico de releitura das obrigações contratuais, relevante se faz compreender o papel do direito constitucional como catalizador da mudança de paradigma de uma teoria contratual rija, que considerava absoluto o princípio da autonomia da vontade, para a dita nova ordem contratual. Esse fenômeno ocorreu também em razão da conquista dos direitos fundamentais de segunda geração, que delegaram à esfera pública uma série de obrigações positivas, deveres de agir, dentre eles, a necessidade de edição de normas cogentes, que visassem ao bem estar social.

Ainda sobre esse importante câmbio, na época das grandes codificações do direito privado do século XIX, as constituições liberais eram tidas como códigos do direito público, disciplinando exclusivamente a organização do Estado, enquanto os códigos privados eram como constituições de direito privado, que regulavam as relações jurídicas entre cidadãos, excluindo-se qualquer intervenção do Estado para além da verificação da ausência de vícios da manifestação de vontade. Até ali, o direito civil e o direito constitucional seguiam caminhos completamente diferentes, cada um no seu próprio âmbito de atuação e, ainda, as constituições não traziam princípios para regular as relações jurídicas privadas. (NETO, 2006, p. 35-36)

André Rufino do Vale (2004, p. 33) assim resume a presença dos direitos fundamentais na concepção liberal clássica, momento histórico que a ciência jurídica traçava uma linha clara entre o público e privado:

Essa concepção unidirecional dos direitos fundamentais tem plantadas suas raízes no primeiro Estado Constitucional, o Estado Liberal de Direito, onde encontrava o marco ideológico idôneo para seu estabelecimento, vinculando-se a uma etapa concreta da história constitucional. Dentro de sua inconfundível característica liberal, os direitos a que hoje chamamos fundamentais, são concebidos, num primeiro momento, como direitos de defesa, ou de omissão, oponíveis unicamente frente ao estado [...]. Dessa forma, essa primeira geração ou, mais especificamente, o núcleo inicial de liberdades individuais, se caracteriza por seu conteúdo negativo. 
Artigo original

Hegemonia - Revista Eletrônica do Programa de Mestrado em Direitos Humanos, Cidadania e Violência/Ciência Política do Centro Universitário Unieuro

ISSN: 1809-1261

UNIEURO, Brasília, número 26, Janeiro a Junho de 2019, pp. 95-113.

É possível dizer que o Código Civil de 1916 era tido como uma constituição privada, que regulamentava a vida do cidadão. Assim, dizia-se que a divisão entre direito público e direito privado era absoluta, uma vez que separava nitidamente o direito público como sendo aquele destinado a regular os interesses sociais ou gerais e o direito privado como sendo o encarregado de regular as relações privadas, ou seja, os interesses individuais ou particulares (FINGER, 2000, p. 86). Aquele Código, por consequência, era notadamente influenciado pelo movimento do Estado Liberal.

A respeito da evolução dos deveres do Estado, migrando de sua concepção clássica que defende a liberdade de contratar para uma visão de Estado Social de Direito, ao tratar do novo marco dos direitos fundamentais, André Rufino do Vale (2004, p. 45) assim esclarece o novo papel que passa a exercer o estado:

Dessa realidade emerge, em oposição aos direitos de defesa na concepção liberal clássica, uma "nova categoria de direitos”, designados como direitos a prestações. Assim, são chamados porque representam exigências de comportamentos estaduais positivos. A relação jurídica fundamental entre indivíduo e Estado não desaparece, mas se transforma: os direitos a prestações não são direitos contra o Estado, mas direitos através do Estado (ações positivas do Estado). Como exemplo, pode-se recorrer à generalidade daqueles direitos que são normalmente designados como direitos sociais: direitos dos trabalhadores, direito à saúde, habitação, educação, cultura, segurança social etc., igualmente chamados de direitos de $2^{a}$ geração.

Guilherme Calmon Nogueira da Gama (2001, p. 25) disserta acerca da importância de se visualizar a relevância de cada um dos dois ramos do direito, o direito público e o direito privado. Contudo, observa-se que ele sustenta a impossibilidade de separá-los, em face da ordem constitucional instaurada em 1988: 
Artigo original

Hegemonia - Revista Eletrônica do Programa de Mestrado em Direitos Humanos, Cidadania e Violência/Ciência Política do Centro Universitário Unieuro

ISSN: 1809-1261

UNIEURO, Brasília, número 26, Janeiro a Junho de 2019, pp. 95-113.

Atualmente, o Direito Civil não pode mais ser visto sob a ótica individualista, tradicional, patrimonialista e conservadora-elitista da época das codificações. Seguindo tendência mundial, no Direito brasileiro, é importante notar o indispensável e relevante papel da Constituição Federal no âmbito do Direito Privado. Aliás, cuida-se de mais um capítulo relativo à propalada dicotomia público/privado, abalando os alicerces edificados pela doutrina tradicional da summa divisio do direito direito público e direito privado.

Cabe ressaltar que, não é novidade alguma o fato de todo o ordenamento jurídico ter por base e limite as disposições constantes na Constituição da República. Todavia, há de se reconhecer que a Carta Federal brasileira vigente trouxe em seu corpo valores e princípios inexistentes nas constituições anteriores, os ditos direitos humanos de $2^{a}$ geração, e daí advém sua importância. No mais, conforme salienta Luís Roberto Barroso (2007, p. 10), o momento presente é marcado pela passagem da Constituição para o centro do sistema jurídico, e mais:

No Brasil, a idéia de que a Constituição era uma norma jurídica, dotada de aplicabilidade direta e imediata, só se desenvolveu a partir da década de 80, consolidando-se com a vigência da Constituição de 1988. Atualmente, passou a ser premissa do estudo do direito constitucional o reconhecimento de sua força normativa, do caráter vinculativo e obrigatório de suas disposições.

No mesmo diapasão, Carlos Alberto da Costa Pinto (2005, p. 73) expõe acerca da impossibilidade de o Código Civil e outras legislações ordinárias albergarem todas as normas aplicáveis às relações privadas, demonstrando que as soluções para essas lacunas devem ser buscadas em normas de direito constitucional:

[...] Problemas de direito civil podem encontrar sua solução numa norma que não é de direito civil, mas de direito constitucional. A Constituição contém, na verdade, uma $<<$ força geradora $>>$ de direito privado. As suas 
Artigo original

Hegemonia - Revista Eletrônica do Programa de Mestrado em Direitos Humanos, Cidadania e Violência/Ciência Política do Centro Universitário Unieuro

ISSN: 1809-1261

UNIEURO, Brasília, número 26, Janeiro a Junho de 2019, pp. 95-113.

normas não são meras directivas programáticas de caráter indicativo, mas normas vinculativas que devem ser acatadas pelo legislador (como decorre logo do princípio da constitucionalidade - art. $3^{\circ}$, n. ${ }^{\circ} 2$ e 3 , da Constituição), pelo juiz e demais órgãos estaduais.

Assim, o direito civil constitucionalizado significa, de fato, uma intervenção estatal no âmbito da vida privada, mas, como visto, essa interferência tem por finalidade proteger o indivíduo de um direito civil rígido e desassociado dos princípios constitucionais, notadamente os direitos fundamentais de segunda e terceira gerações, abarcados nas constituições da pósmodernidade.

É indiscutível a supremacia dos valores, dos princípios implícitos e explícitos, das regras programáticas e das disposições concretas adotadas pela Constituição Federal de 1988, sobre todo o ordenamento jurídico. Desta feita, as regras assumidas pelo Código Civil de 2002 deverão ser interpretadas em conformidade com a vontade contida na Carta Superior, assim como ocorre em todos os ramos do direito. (DELGADO, 2003, p. 393)

Nessa perspectiva, Paulo Lôbo (2002), ao tratar da função social do contrato, ensina que:

A função exclusivamente individual do contrato é incompatível com o Estado social, caracterizado, sob o ponto de vista do direito, como já vimos, pela tutela explícita da ordem econômica e social na Constituição. $\mathrm{O}$ art. 170 da Constituição brasileira estabelece que toda a atividade econômica - e o contrato é o instrumento dela - está submetida à primazia da justiça social. Não basta a justiça comutativa que o liberalismo jurídico entendia como exclusivamente aplicável ao contrato. Enquanto houver ordem econômica e social haverá Estado social; enquanto houver Estado social haverá função social do contrato. $[\cdots]$

No novo Código Civil a função social surge relacionada à "liberdade de contratar", como seu limite fundamental. A liberdade de contratar, ou autonomia privada, consistiu na expressão mais aguda do individualismo 
Artigo original

Hegemonia - Revista Eletrônica do Programa de Mestrado em Direitos Humanos, Cidadania e Violência/Ciência Política do Centro Universitário Unieuro

ISSN: 1809-1261

UNIEURO, Brasília, número 26, Janeiro a Junho de 2019, pp. 95-113.

jurídico, entendida por muitos como o toque de especificidade do direito privado. São dois princípios antagônicos que exigem aplicação harmônica. No Código a função social não é simples limite externo ou negativo mas limite positivo, além de determinação do conteúdo da liberdade de contratar. Esse é o sentido que decorre dos termos "exercida em razão e nos limites da função social do contrato" (art. 421).

O mencionado autor ressalta que, segundo o modelo do moderno direito constitucional, o contrato deve ser interpretado em conformidade com o princípio da função social, o que justamente reafirma a necessidade de interpretação dos pactos privados sob a ótica principiológica e normativa apresentada na Carta Federal.

E é nesse ponto que se pode afirmar, a par de tudo já registrado, a possibilidade de, diante do caso concreto, mitigar o princípio do pacta sunt servanda, para adequar o contrato aos princípios constitucionais e não só à estrita vontade dos contratantes.

Isso porque, conforme ressalta Claudia Lima Marques (2002, p. 52), fica pendente na balança do direito, de um lado: a liberdade de contratar, de se auto-obrigar, na acepção clássica do contrato; e, de outro, a necessidade de regular uma sociedade que contrata em massa, sem conhecer os termos em que se vincula, não havendo mais, com tanta frequência, o contrato paritário ou individual, em que se discutia cláusula a cláusula.

Nesse contexto a Constituição da República exerce um papel balizador, pois estabelece o standart de conduta, ao garantir a função social da propriedade em seu art. $5^{\circ}$ e, por conseguinte, a função social do contrato, axioma que não sobrevive sem a boa-fé objetiva.

Sobre esse standart de conduta e boa-fé objetiva Cláudia Lima Marques acentua que trata-se de:

(...) uma atuação "refletida", pensando no outro, no parceiro contratual, respeitando seus interesses legítimos, seus direitos, respeitando os fins do contrato, agindo com lealdade, sem abuso da posição contratual, sem causar lesão ou desvantagem excessiva, com cuidado com a pessoa e o patrimônio do parceiro contratual, cooperando para atingir o bom fim 
Artigo original

Hegemonia - Revista Eletrônica do Programa de Mestrado em Direitos Humanos, Cidadania e Violência/Ciência Política do Centro Universitário Unieuro

ISSN: 1809-1261

UNIEURO, Brasília, número 26, Janeiro a Junho de 2019, pp. 95-113.

das obrigações, isto é, o cumprimento do objetivo contratual e a realização dos interesses legítimos de ambos os parceiros.

Trata-se de uma boa-fé objetiva, um paradigma de conduta leal, e não apenas da boa-fé subjetiva, conhecida regra de conduta subjetiva do artigo 1444 do CCB [1916]. Boa-fé objetiva é um standard de comportamento leal, com base na confiança, despertando na outra parte co-contratante, respeitando suas expectativas legítimas e contribuindo para a segurança das relações negociais. (1999, P. 145)

Por conseguinte todas normas do ordenamento jurídico precisam ser lidas sob a nova ótica do Estado Social de Direito, tal qual concebido pela Constituição de 1988, nesse sentido, Orlando de Carvalho (1981, p. 50-51) anota que, não há direito que se permita existir atemporalmente, alheio aos demais valores, conflitos e elementos sociais que caracterizam um contexto. Assim, “[...] mesmo que as normas não mudem, muda o entendimento das normas $[\cdots] "$.

O Código de Defesa do Consumidor - CDC (assegurado como direito e garantia fundamental no inciso XXXII do art. $5^{\circ}$, assim como princípio da ordem econômica, no art. 170, inciso V, ambos da Constituição Federal) surge na história do direito brasileiro, no ano de 1990, como o primeiro diploma legal a definir expressamente a boa-fé objetiva como elemento central da relação contratual.

É importante compreender que, na visão do CDC, a boa-fé objetiva tem por fim equilibrar as relações de consumo, ciente de que o consumidor, na maior parte das vezes em que celebra um contrato, está em condição de inferioridade, sujeito a abusos, até porque, muitas vezes apenas adere aos termos do contrato imposto (contratação em massa). Daí a relevância da leitura da relação contratual de consumo pelo filtro da boa-fé, do princípio da transparência e da confiança. Também por esse motivo o ordenamento consumerista dispõe de diversos artigos que manifestam normas cogentes que visam equilibrar a relação de consumo e proteger a sociedade como todo. 
Artigo original

Hegemonia - Revista Eletrônica do Programa de Mestrado em Direitos Humanos, Cidadania e Violência/Ciência Política do Centro Universitário Unieuro

ISSN: 1809-1261

UNIEURO, Brasília, número 26, Janeiro a Junho de 2019, pp. 95-113.

De outra banda, em 10 de janeiro de 2002, outro marco legislativo institui o Código Civil vigente, que, naturalmente, vem em absoluta consonância com o já preconizado na Carta Federal e no Código de Defesa do Consumidor.

No entanto, há que se observar que, em que pese a visão de proteção do CDC ser a mesma pretendida pelo Código Civil de 2002, a forma em que se externa a observância dos direitos e garantias fundamentais previstas na $\mathrm{CR} / 88$ são distintas. Isso porque o novo diploma legal trata as partes de forma isonômica, mas foca na intenção e manifestação de vontade verdadeiramente pretendida em seus institutos, assim como a função social do contrato e os deveres de lealdade e de probidade entre as partes já trabalhados aqui pelos pensamentos de Paulo Lôbo e Cláudia Lima Marques. Portanto, conquanto não haja presunção de disparidade, em sendo qualquer violação verificada em juízo deve-se observar os princípios constitucionais supra mencionados para dar limite à liberdade de contratar.

Christiano Cassettari (2009) define bem o diálogo estabelecido entre o Estatuto Consumerista e o Código Civil, quando assim assevera:

Novos princípios foram introduzidos na teoria geral dos contratos com o advento do Código Civil vigente, que aproximaram, e muito, do Código de Defesa do Consumidor. Refiro-me aos princípios da função social do contrato e da boa-fé objetiva, descritos, respectivamente, nos artigos 421 e 424 da novel legislação.

Ao fim e ao cabo, o que se percebe é que o fenômeno da constitucionalização do direito civil permitiu ao operador do direito estabelecer uma leitura mais humanizada das relações entre particulares, de modo a assegurar a observância dos princípios constitucionais de forma ampla e difusa.

\section{SOLUÇÃO DE CONFLITO DE PRINCÍPIOS CONSTITUCIONAIS}

Com efeito, guardada a importância da constitucionalização do direito privado para as relações civis, é também certo que essa integração deve encontrar balizas, para fins de jamais enrijecer a liberdade da conduta humana no âmbito das suas relações privadas. 
Artigo original

Hegemonia - Revista Eletrônica do Programa de Mestrado em Direitos Humanos, Cidadania e Violência/Ciência Política do Centro Universitário Unieuro

ISSN: 1809-1261

UNIEURO, Brasília, número 26, Janeiro a Junho de 2019, pp. 95-113.

A esse respeito, Sílvio de Salvo Venosa (2003, p. 376) assim enfrenta os excessos que podem ser cometidos na ânsia de se regular, com a edição de normas cogentes do Estado, todos os elementos das relações jurídicas entre particulares:

Assim, a lei procurou dar aos mais fracos uma superioridade jurídica para compensar a inferioridade econômica. Nem sempre o Estado mostrouse bem-sucedido na tarefa. A excessiva intervenção na ordem econômica privada ocasiona distorções a longo prazo. A legislação do inquilinato é exemplo típico. A denominada proteção ao inquilino desestimula as construções e, consequentemente, faltam imóveis para locar. A atual lei inquilinária (Lei no 8.245/91) procura corrigir a distorção. Nas legislações pretéritas, atingia-se exatamente o oposto do pretendido pela lei. Como é lenta a tarefa legislativa, uma vez distorcida a economia, dificilmente se volta ao estágio anterior, principalmente porque o cidadão passa a desconfiar do Estado, o qual, a qualquer momento, pode intervir em seu patrimônio privado.

Notadamente, existe um aparente conflito: de um lado, a livre iniciativa e, de outro, a intervenção do Estado na ordem econômica. Sobre isso, André Rufino do Vale (2004, p. 189) registra que:

Como já analisado, no âmbito das relações jurídicas privadas, as colisões costumam ocorrer entre a autonomia privada e outros direitos fundamentais. O problema, portanto, está em encontrar critérios que determinem quando deverá prevalecer a autonomia privada dos indivíduos, de modo a que possam regular suas próprias relações num espaço alheio aos direitos e garantias fundamentais, e, por outro lado, quando esses direitos e garantias devem ser obrigatoriamente observados na confecção dessas relações privadas. 
Artigo original

Hegemonia - Revista Eletrônica do Programa de Mestrado em Direitos Humanos, Cidadania e Violência/Ciência Política do Centro Universitário Unieuro

ISSN: 1809-1261

UNIEURO, Brasília, número 26, Janeiro a Junho de 2019, pp. 95-113.

Uma hermenêutica fecunda pode ser encontrada em Robert Alexy (2007, p. 92), quando aponta para os possíveis conflitos entre princípios e as consequentes exceções que merecem tratamento especial na dialética jurídica. Ao fazê-lo, recorre ao axioma da precedência, nos seguintes moldes:

Sólo sobre la base de un cuidadoso análisis de la respectiva situación, y de una ponderación justa de todos los intereses que están en juego, es posible decidir, en el caso particular, a cuáles resultados conduce esta referencia general que, sin embarco, muchas veces, permite, sin más, una decisión inequivoca.

Nota-se que, somente com a análise jurisdicional de cada caso, será possível estabelecer se a mitigação do pacta sunt servanda em face da boa-fé objetiva trará justiça à pretensão resistida levada a juízo. Conclui o mesmo autor que: Una norma de derecho fundamental sólo tienen validez si, y en la medida en que, no se contraponga ningún interés (bien jurídico) de un rango mayor a los intereses de libertad que la norma protege. (ALEXY, 2007, p 92).

Para fins de melhor esclarecer como se dá a aplicação do principio da precedência, relevante citar aqui um exemplo de colisão de direitos fundamentais no âmbito privado, analisado pelo Tribunal Constitucional Alemão, denominado assassinato de soldados de Lebach. (VALE, 2004, p. 186-188)

O caso trata de ação judicial proposta em razão de um documentário veiculado no Segundo Programa de Televisão, que relatava um homicídio cometido contra quatro soldados que guardavam um depósito de munição do Exército Federal alemão, perto da cidade de Lebach.. Um cúmplice, condenado por ter tido participação de menor importância, teve seu nome publicado no programa.

Esse partícipe, por sua vez, ajuizou a mencionada ação contra o canal alemão, pleiteando a supressão de sua identidade do documentário, pois considerou que a veiculação de seu nome e fotografia violou seu direito de ter a personalidade protegida e, também, considerou que sua ressocialização restava prejudicada em face da ampla publicidade dada.

Em primeira instância, sua pretensão não encontrou abrigo o que, somente em análise jurisdicional de terceiro nível, portanto, quando da apreciação do Tribunal Constitucional, considerou-se que se fazia mister a "ponderação dos direitos em colisão por meio do 
Artigo original

Hegemonia - Revista Eletrônica do Programa de Mestrado em Direitos Humanos, Cidadania e Violência/Ciência Política do Centro Universitário Unieuro

ISSN: 1809-1261

UNIEURO, Brasília, número 26, Janeiro a Junho de 2019, pp. 95-113.

estabelecimento de uma relação de precedência condicionada" (VALE, 2004, p. 187) e valorar que, em face do conflito entre a proteção da personalidade e o direito à informação, o caso concreto merecia a prevalência daquele.

Assim, o acusado teve sua ação julgada procedente, reconhecendo-se que existiu a violação ao seu direito à proteção da personalidade.

Dessarte, voltando para o tema central ora abordado, conquanto resta clara a mitigação da autonomia da vontade clássica, em face de um direito social, da coletividade, já sedimentados no ordenamento pátrio, a precedência condicionada deve ser aplicada nos casos concretos, para dar especial atenção ao conflito aparente entre a livre iniciativa e alguma garantia constitucional. Desde que, com essa valoração, observe-se qual bem jurídico resta prejudicado e merece maior atenção.

\section{CONSIDERAÇÕES FINAIS}

A evolução da boa-fé objetiva por meio da compreensão do direito como instrumento de transformação do Estado Social sobre a coletividade finalmente alcançou a autonomia da vontade na celebração dos contratos para abarcar a tese de que os princípios da boa-fé (subjetiva e objetiva) derivam da função social do contrato, perspectiva que, como dito anteriormente, está amparada na visão da expectativa dos interesses coletivos como núcleo dos contratos.

A guarda desse interesse social objetivo, segundo Cláudia Maria Marques (1999, p. 150-239), é derivada especificamente da visão socializante dos instrumentos jurídicos para realização das vontades dos indivíduos.

O novo modelo para o estabelecimento dos contratos emprega uma revalorização dos termos tradicionais do direito. Nesse contexto, a liberdade das partes passa a obedecer a uma valoração de autonomia real da vontade, em que a liberdade que limita o outro passa a ser combatida e o exercício do Direito se dá com o fulcro de proteger o mais fraco contra excessos da parte mais forte. (MARQUES, 2002, p. 169-171)

Nesse sentido, a visão da boa-fé enquanto variável decorrente da socialização do Direito justifica melhor os propósitos do Estado brasileiro moderno. Deve-se guardar, contudo, 
Artigo original

Hegemonia - Revista Eletrônica do Programa de Mestrado em Direitos Humanos, Cidadania e Violência/Ciência Política do Centro Universitário Unieuro

ISSN: 1809-1261

UNIEURO, Brasília, número 26, Janeiro a Junho de 2019, pp. 95-113.

que somente na análise de casos concretos, em sede judicial, é possível delimitar os contornos finais da liberdade de contratar em oposição ao direito social.

\section{REFERENNCIAS}

ALEXY, Robert. Teoría de los derechos fundamentales. 2. ed. Madrid: Sociedad Anónima de Fotocomposición, 2007.

AZEVEDO, Álvaro Villaça de; TEIXEIRA, Sálvio de Figueiredo coord. Comentários ao Novo Código Civil: das várias espécies de contratos. Da compra e venda. V. 7. Rio de Janeiro: Forense, 2005.

BARROSO, Luís Roberto. A reconstrução democrática do direito público no Brasil. Rio de Janeiro: Renovar, 2007.

BRASIL. Constituição da República Federativa do Brasil: promulgada em 5 de outubro de 1988. Disponível em:

http://www.planalto.gov.br/ccivil_03/constituicao/ConstituicaoCompilado.htm> Acesso em 17 nov. 2015.

BRASIL. Lei n. 10.406, de 11 de janeiro de 2002. Disponível em: <http://www.planalto.gov.br/ccivil_03/leis/2002/L10406compilada.htm>. Acesso em 17 nov. 2015.

BITTAR FILHO, Carlos Alberto. Teoria da imprevisão: sentido atual. Revista dos Tribunais, São Paulo, v. 679, ano 81, p. 18-29, mar. 1992.

CARVALHO, Orlando de. Para uma teoria geral da relação jurídica. v. I, 2. ed. Coimk Centelha, 1981.

DELGADO, José Augusto. O Código Civil de 2002 e a Constituição Federal de 1988. Cláusulas gerais e conceitos indeterminados. In ALVIM, Arruda; CÉSAR, Joaquim Portes de Cerqueira e ROSAS, Roberto. Aspectos controvertidos do novo Código Civil. São Paulo: Editora Revista dos Tribunais, 2003.

DINIZ, Maria Helena. Teoria das obrigações contratuais e extracontratuais. v. 3. 17. ed. rev. atual. São Paulo: Saraiva, 2002.

DONNINI, Rogério Ferraz. A revisão dos contratos no Código Civil e no Código de Defesa do Consumidor. 2. ed. São Paulo: Saraiva, 2001. 
Artigo original

Hegemonia - Revista Eletrônica do Programa de Mestrado em Direitos Humanos, Cidadania e Violência/Ciência Política do Centro Universitário Unieuro

ISSN: $1809-1261$

UNIEURO, Brasília, número 26, Janeiro a Junho de 2019, pp. 95-113.

DUQUE, Bruna Lyra. A revisão dos contratos e a teoria da imprevisão: uma releitura do Direito contratual à luz do princípio da socialidade. Panóptica, Vitória, ano 1, n. 8, maio - junho, 2007. Disponível em: <http://www.panoptica.org>. Acesso em: 14 nov. 2015.

FINGER, Julio César. Constituição e direito privado: algumas notas sobre a chamada constitucionalização do direito civil. In SARLET, Ingo Wolfgang. A Constituição concretizada: construindo pontes com o público e o privado. Porto Alegre: Livraria do Advogado, 2000.

GAMA, Guilherme Nogueira da. Direito de família brasileiro: Introdução - abordagem sob a perspectiva civil-constitucional. São Paulo: Editora Juarez de Oliveira, 2001.

GEHLEN, Gabriel Menna Barreto Von. O chamado direito civil constitucional. In MARTINSCOSTA, Judith. A Reconstrução do direito privado: reflexos dos princípios, diretrizes e direitos fundamentais constitucionais no direito privado. São Paulo: Editora Revista dos Tribunais, 2002. LOUREIRO, Luiz Guilherme. Teoria geral dos contratos no Novo Código Civil. São Paulo: Método, 2002.

LÔBO, Paulo. Princípios sociais dos contratos no CDC e no novo Código Civil. Revista Jus Navigandi, Teresina, ano 7, n. 55, 1 mar. 2002. Disponível em: <http://jus.com.br/artigos/2796>. Acesso em: 16 nov. 2015.

MARQUES, Cláudia Lima. Contratos no Código de Defesa do Consumidor. 3. ed. São Paulo: Revista dos Tribunais, 1999.

Contratos no Código de Defesa do Consumidor. 4. ed. São Paulo: Revista dos Tribunais, 2002.

Planos privados de assistência à saúde. Desnecessidade de opção do consumidor pelo novo sistema. Opção a depender da conveniência do consumidor. Abusividade da cláusula contratual que permite a resolução do contrato coletivo por escolha do fornecedor. Revista de Direito do Consumidor, n 31 , jul./set./99.

NEGREIROS, Teresa. Teoria do contrato: novos paradigmas. 2. ed. Rio de Janeiro: Renovar, 2006.

NETO, Eugênio Facchini. Reflexões histórico-evolutivas sobre a constitucionalização do direito privado. In SARLET, Ingo Wolfgang (org.). Constituição, direitos fundamentais e direito privado. Porto Alegre: Livraria do Advogado Editora, Porto Alegre, 2006.

PERLINGIERI, Pietro. Perfis do direito civil. 3. ed. rev. ampl. Rio de Janeiro: Renovar, 2002. 
Artigo original

Hegemonia - Revista Eletrônica do Programa de Mestrado em Direitos Humanos, Cidadania e Violência/Ciência Política do Centro Universitário Unieuro

ISSN: 1809-1261

UNIEURO, Brasília, número 26, Janeiro a Junho de 2019, pp. 95-113.

PINTO, Carlos Alberto da Mota. Teoria geral do direito civil. 4. ed. Coimbra: Coimbra Editora, 2005.

RAWLS, John. A ideia de elementos constitucionais essenciais. In RAWLS, John. Tradução de Dinah de Abreu Azevedo. Liberalismo político. São Paulo: Atica, 2000.

RIPERT, George. La règle morale dans les obligations civiles. 4. ed. Paris: Librairie Génerale de Droit et Jurisprudence, 1949.

ROGERS, Henry Wade. The Law-Making Power. 1894. Faculty Scholarship Series. Yale Law School. Paper 4082 <http://digitalcommons.law.yale.edu/fss_papers/4082>. Acesso em: 14. nov. 2015.

ROSE, R. S. Uma das coisas esquecidas: Getúlio Vargas e o controle social dos brasileiros. Tradução de Anna Olga de Barros Barreto. São Paulo: Companhia das Letras, 2001.

SALVADOR, Manuel Júlio Gonçalves. A boa-fé nas obrigações, natureza e definição. In Revista dos Tribunais, ano 86. Porto: Sociedade de Papelaria, 1968.

SANTIAGO, Mariana Ribeiro. O princípio da função social do contrato: princípios contratuais, contrato eletrônico, contrato coletivo, contrato-tipo, direito comparado, boa-fé. Curitiba: Juruá, 2005.

VALE, André Rufino do. Eficácia dos direitos fundamentais nas relações privadas. Porto Alegre: Sergio Antonio Fabris, 2004.

VENOSA, Sílvio de Salvo. Teoria geral das obrigações e teoria geral dos contratos. 3. ed. V. 2. São Paulo: Atlas, 2003.

WIEACKER, Franz. História do direito privado. 2. ed., trad. A. M. Botelho Hespanha, Lisboa: Fundação Calouste Gulbenkian, 1993. 